Supplement of The Cryosphere, 12, 2707-2726, 2018

https://doi.org/10.5194/tc-12-2707-2018-supplement

(C) Author(s) 2018. This work is distributed under

the Creative Commons Attribution 4.0 License.

(c) (1)

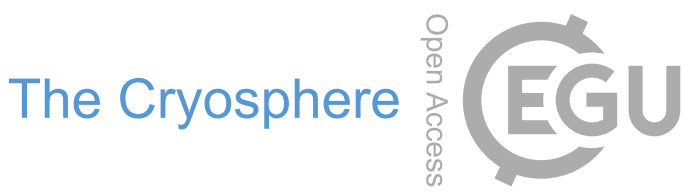

Supplement of

\title{
Diagnosing ice sheet grounding line stability from landform morphology
}

Lauren M. Simkins et al.

Correspondence to: Lauren M. Simkins (1simkins@virginia.edu)

The copyright of individual parts of the supplement might differ from the CC BY 4.0 License. 


\section{S1. Supplementary Methods}

Grounding line landforms were mapped into three groups including grounding zone wedges, recessional moraines, and crevasse squeeze ridges in ArcGIS using NBP1502A and legacy multibeam data collected aboard the RVIB Nathaniel B. Palmer. Landforms displaying asymmetric morphologies and smeared surficial appearances resulting from relatively broad stoss widths (compared to lee widths) were interpreted as grounding zone wedges, whereas symmetric, quasi-linear landforms with regular spacing were interpreted as recessional moraines. Identified landforms are within fields of like landforms. Within one field of recessional moraines, erratically shaped landforms with variable orientations and irregular amplitudes that are generally greater than that of the recessional moraines were interpreted as crevasse squeeze ridges. Morphometrics for grounding zone wedges and recessional moraines were generated from transects across landforms using the 'findpeaks' function in Matlab. Measured properties include (1) amplitude measured from landform crestlines, (2) width in the along-flow direction, (3) spacing between adjacent landform peaks, and (4) asymmetry measured as the ratio of offset between the peak location and the half width point, where a landform with a value of 0 has a peak directly above the half width point and is classified as symmetric and a landform with an asymmetry of 1 has a peak furthest from the half width point and displays the most pronounced asymmetry. Landform sinuosity was extracted from the mapped landforms in ArcGIS, calculated by dividing the true landform length by the straight-line length between landform end points. Crosssectional area of landforms was calculated assuming a triangular cross-profile shape.

The topographic context of individual landforms was characterized by water depth, seafloor (bed) slope and bed aspect with respect to the landform. At the center-point of each mapped landform, the present-day water depth was extracted from the IBCSO (International Bathymetric Chart of the Southern Ocean; Arndt et al., 2013) 500-m grid, present-day bed slope from a 5-km slope grid derived from IBCSO, and bed aspect from the same grid measured in degrees. The offset between landform orientation and bed aspect was then derived and transformed onto a $0-90^{\circ}$ scale, in which $0^{\circ}$ denotes a landform whose long axis is oriented perpendicular to slope contours ('downslope', i.e. landform is oriented in the same direction that the bed dips) and $90^{\circ}$ denotes a landform oriented parallel to slope contours ('across slope'). We only analyze landform orientation with respect to bed aspect where a bed slope is actually present, defined as a slope $>0.1^{\circ}$.

\section{S2 References for grounding zone wedge $[\mathrm{gzw}]$ and moraine $[\mathrm{m}]$ morphometry data plotted in Fig. 5B, C.}

Aartolahti, T., Koivisto, M., and Nenonen, K.: De Geer moraines in Finland. Spec. Paper-Geol. Surv. of Finland, 67-74, 2015. [m]

Anandakrishnan, S., Catania, G. A., Alley, R. B., and Horgan, H. J.: Discovery of till deposition at the grounding line of

Whillans Ice Stream. Science, 315(5820), 1835-1838, 2007 [gzw]

Arndt, J. E. and Evans, J.: Glacial lineations and recessional moraines on the continental shelf of NE Greenland. Geol. Soc., London, Memoirs, 46(1), 263-264, 2016. [m]

Anderson, J. B. and Bartek, L. R.: Ross Sea glacial history revealed by high resolution seismic reflection data combined with drill site information. The Antarctic Paleoenvironment: A perspective on global change (1), AGU Ant. Res. Ser., 56, 231-

263, 1992. [gzw]

Anderson, J. B., Shipp, S. S., Bartek, L. R., and Reid, D. E.: Evidence for a grounded ice sheet on the Ross Sea continental shelf during the late Pleistocene and preliminary paleodrainage reconstruction. Contrib. to Ant. Res. III, 39-62, 1992. [gzw] Anderson, J. B.: Grounding zone wedges on the Antarctic continental shelf, Weddell Sea. In Glaciated Continental Margins (pp. 98-99). Springer Netherlands, 1997. [gzw]

Anderson, J. B.: Antarctic marine geology. Cambridge University Press, 1999. [gzw]

Anderson, J. B., Shipp, S. S., Lowe, A. L., Wellner, J. S., and Mosola, A. B.:. The Antarctic Ice Sheet during the Last Glacial Maximum and its subsequent retreat history: a review. Quat. Sci. Rev., 21(1), 49-70, 2002. [gzw] 
Andreassen, K., Laberg, J. S., and Vorren, T. O...Seafloor geomorphology of the SW Barents Sea and its glaci-dynamic implications. Geomorph., 97(1), 157-177, 2008. [gzw]

45 Andreassen, K., Winsborrow, M. C., Bjarnadóttir, L. R., and Rüther, D. C.: Ice stream retreat dynamics inferred from an assemblage of landforms in the northern Barents Sea. Quat. Sci. Rev., 92, 246-257, 2014. [gzw]

Bart, P. J. and Owolana, B.: On the duration of West Antarctic Ice Sheet grounding events in Ross Sea during the Quaternary. Quat. Sci. Rev., 47, 101-115, 2012. [gzw]

Bart, P. J.: West-directed flow of the West Antarctic Ice Sheet across eastern basin, Ross Sea during the

50 Quaternary. EPSL, 228(3), 425-438, 2004. [gzw]

Batchelor, C. L., Dowdeswell, J. A., and Pietras, J. T.: Variable history of Quaternary ice-sheet advance across the Beaufort Sea margin, Arctic Ocean. Geol., 41(2), 131-134, 2013. [gzw]

Batchelor, C. L., Dowdeswell, J. A., and Pietras, J. T.: Seismic stratigraphy, sedimentary architecture and palaeo-glaciology of the Mackenzie Trough: evidence for two Quaternary ice advances and limited fan development on the western Canadian

55 Beaufort Sea margin. Quat. Sci. Rev., 65, 73-87, 2013. [gzw]

Batchelor, C. L., Dowdeswell, J. A., and Pietras, J. T. Evidence for multiple Quaternary ice advances and fan development from the Amundsen Gulf cross-shelf trough and slope, Canadian Beaufort Sea margin. Marine and Petroleum Geol., 52, 125143, 2014. [gzw]

Bentley, M. J. and Anderson, J. B.: Glacial and marine geological evidence for the ice sheet configuration in the Weddell

60 Sea-Antarctic Peninsula region during the Last Glacial Maximum. Ant. Sci.,10(3), 309-325, 1998. [gzw]

Bjarnadóttir, L. R., Rüther, D. C., Winsborrow, M., and Andreassen, K.: Grounding-line dynamics during the last deglaciation of Kveithola, W Barents Sea, as revealed by seabed geomorphology and shallow seismic stratigraphy. Boreas, 42(1), 84-107, 2013. [gzw]

Bøe, R., Bellec, V. K., Dolan, M. F. J., Buhl-Mortensen, P., Rise, L., and Buhl-Mortensen, L.: Cold-water coral reefs in the 65 Hola glacial trough off Vesterålen, North Norway. Geol. Soc., London, Memoirs, 46(1), 309-310, 2016. [gzw]

Bradwell, T., Stoker, M. S., Golledge, N. R., Wilson, C. K., Merritt, J. W., Long, D., ... and Finlayson, A. G.: The northern sector of the last British Ice Sheet: maximum extent and demise. Earth-Sci. Rev., 88(3), 207-226, 2008. [gzw]

Bradwell, T. and Stoker, M. S: Glacial sediment and landform record offshore NW Scotland: a fjord-shelf-slope transect through a Late Quaternary mid-latitude ice-stream system. Geol. Soc., London, Memoirs, 46(1), 421-428, 2016. [gzw]

70 Bradwell, T., Fabel, D., Stoker, M., Mathers, H., McHargue, L., and Howe, J.: Ice caps existed throughout the Lateglacial Interstadial in northern Scotland. J. of Quat. Sci., 23(5), 401-407, 2008. [gzw]

Christ, A. J., Talaia-Murray, M., Elking, N., Domack, E. W., Leventer, A., Lavoie, C., ... and Petrushak, S.: Late Holocene glacial advance and ice shelf growth in Barilari Bay, Graham Land, west Antarctic Peninsula. Geol. Soc. of Amer.

Bull., 127(1-2), 297-315, 2015. [m]

75 Dickens, W. A., Graham, A. G. C., Smith, J. A., and Dowdeswell, J. A. Large, buried glacial moraines revealed by TOPAS sub-bottom profiling, South Orkney Islands, South Atlantic Ocean. Geol. Soc., London, Memoirs, 46(1), 251-252, 2016. [gzw]

Domack, E., O'Brien, P., Harris, P., Taylor, F., Quilty, P. G., De Santis, L., and Raker, B.: Late Quaternary sediment facies in Prydz Bay, East Antarctica and their relationship to glacial advance onto the continental shelf. Ant. Sci., 10(3), 236-246, 1998. [m]

Dowdeswell, J. A. and Ottesen, D.: Current-modified recessional-moraine ridges on the NW Spitsbergen shelf. Geol. Soc., London, Memoirs, 46(1), 255-256, 2016. [m]

Dowdeswell, J. A. and Fugelli, E. M. G.: The seismic architecture and geometry of grounding-zone wedges formed at the marine margins of past ice sheets. Geol. Soc. Of Amer. Bull., 124(11-12), 1750-1761, 2012. [gzw] 
Dowdeswell, J. A., Ottesen, D., and Rise, L.: Skjoldryggen terminal moraine on the mid-Norwegian Shelf. Geol. Soc., London, Memoirs, 46(1), 249-250, 2016. [m]

Dowdeswell, J. A., Ottesen, D., Evans, J., Cofaigh, C. O., and Anderson, J. B.: Submarine glacial landforms and rates of icestream collapse. Geol., 36(10), 819-822, 2008. [gzw]

Dowdeswell, J. A., Hogan, K. A., Cofaigh, C. Ó., Fugelli, E. M. G., Evans, J., and Noormets, R.: Late Quaternary ice flow in

a West Greenland fjord and cross-shelf trough system: submarine landforms from Rink Isbrae to Uummannaq shelf and slope. Quat. Sci. Rev., 92, 292-309, 2014. [gzw]

Dunlop, P., Shannon, R., McCabe, M., Quinn, R., and Doyle, E.: Marine geophysical evidence for ice sheet extension and recession on the Malin Shelf: New evidence for the western limits of the British Irish Ice Sheet. Marine Geol., 276(1-4), 8699, 2010. [m]

95 Elvenes, S. and Dowdeswell, J. A.: Possible 'lift-off moraines' at grounded ice-sheet margins, North Norwegian shelf edge. Geol. Soc., London, Memoirs, 46(1), 247-248, 2016. [m]

Elvenes, S., Bøe, R., and Rise, L.: Post-glacial sand drifts burying De Geer moraines on the continental shelf off North Norway. Geol. Soc., London, Memoirs, 46(1), 261-262, 2016. [m]

Evans, J., Pudsey, C. J., ÓCofaigh, C., Morris, P., and Domack, E.: Late Quaternary glacial history, flow dynamics and sedimentation along the eastern margin of the Antarctic Peninsula Ice Sheet. Quat. Sci. Rev., 24(5-6), 741-774, 2005. [gzw] Evans, J., Dowdeswell, J. A., Cofaigh, C. Ó., Benham, T. J., and Anderson, J. B.: Extent and dynamics of the West Antarctic Ice Sheet on the outer continental shelf of Pine Island Bay during the last glaciation. Marine Geol., 230(1-2), 53-72, 2006. [gzw]

Forwick, M. and Vorren, T. O.: Stratigraphy and deglaciation of the Isfjorden area, Spitsbergen. Norwegian Journal of 105 Geol./Norsk Geologisk Forening, 90(4), 2010. [gzw]

Gilbert, R., Domack, E. W., and Camerlenghi, A.: Deglacial history of the Greenpeace Trough: ice sheet to ice shelf transition in the northwestern Weddell Sea. Antarctic Peninsula Climate Variability: Hist. and Paleoenviron. Perspec., 195204, 2003. [gzw]

Graham, A. G., Larter, R. D., Gohl, K., Dowdeswell, J. A., Hillenbrand, C. D., Smith, J. A., ... and Deen, T.: Flow and 110 retreat of the Late Quaternary Pine Island-Thwaites palaeo-ice stream, West Antarctica. JGR: Earth Surf., 115(F3), 2010. [gzw]

Graham, A. G., Kuhn, G., Meisel, O., Hillenbrand, C. D., Hodgson, D. A., Ehrmann, W., ,.. and White, D.: Major advance of South Georgia glaciers during the Antarctic Cold Reversal following extensive sub-Antarctic glaciation. Nat. Comm., 8 , 14798, 2017. [gzw]

115 Gohl, K., Uenzelmann-Neben, G., Larter, R. D., Hillenbrand, C. D., Hochmuth, K., Kalberg, T., ... and Nitsche, F. O.: Seismic stratigraphic record of the Amundsen Sea Embayment shelf from pre-glacial to recent times: Evidence for a dynamic West Antarctic ice sheet. Marine Geol., 344, 115-131, 2013. [gzw]

Greenwood, S. L., Gyllencreutz, R., Jakobsson, M., and Anderson, J. B.: Ice-flow switching and East/West Antarctic Ice Sheet roles in glaciation of the western Ross Sea. Geol. Soc. of Amer. Bull., 124(11-12), 1736-1749, 2012. [gzw]

120 Heroy, D. C. and Anderson, J. B.: Ice-sheet extent of the Antarctic Peninsula region during the Last Glacial Maximum (LGM) - Insights from glacial geomorphology. Geol. Soc. of Amer. Bull., 117(11-12), 1497-1512, 2005. [gzw]

Hogan, K. A., Dowdeswell, J. A., Noormets, R., Evans, J., Cofaigh, C. Ó., and Jakobsson, M.: Submarine landforms and icesheet flow in the Kvitøya Trough, northwestern Barents Sea. Quat. Sci. Rev., 29(25), 3545-3562, 2010. [gzw]

Hogan, K. A., Dowdeswell, J. A., and Noormets, R.: Assemblages of submarine landforms in the glacial troughs of the

125 northern Barents Sea, east of Svalbard. Geol. Soc., London, Memoirs, 46(1), 333-336, 2016. [m]

Howat, I. M. and Domack, E. W.: Reconstructions of western Ross Sea palaeo-ice-stream grounding zones from highresolution acoustic stratigraphy. Boreas, 32(1), 56-75, 2003. [gzw] 
Jamieson, S. S., Vieli, A., Livingstone, S. J., Cofaigh, C. Ó., Stokes, C., Hillenbrand, C. D., and Dowdeswell, J. A.: Icestream stability on a reverse bed slope. Nat. Geo., 5(11), 799, 2012 [gzw]

Kirshner, A. E., Anderson, J. B., Jakobsson, M., O’Regan, M., Majewski, W., and Nitsche, F. O.: Post-LGM deglaciation in Pine Island Bay, west Antarctica. Quat. Sci. Rev., 38, 11-26, 2012. [gzw]

Klages, J. P., Kuhn, G., Hillenbrand, C. D., Graham, A. G., Smith, J. A., Larter, R. D., and Gohl, K.: A glacial landform assemblage from an inter-ice stream setting in the eastern Amundsen Sea Embayment, West Antarctica. Geol. Soc., London, Memoirs, 46(1), 349-352, 2016. [m]

135 Klages, J. P., Kuhn, G., Hillenbrand, C. D., Graham, A. G. C., Smith, J. A., Larter, R. D., and Gohl, K.: First geomorphological record and glacial history of an inter-ice stream ridge on the West Antarctic continental shelf. Quat. Sci. Rev., 61, 47-61, 2013. [m]

Klages, J. P., Kuhn, G., Hillenbrand, C. D., Graham, A. G., Smith, J. A., Larter, R. D., ... and Wacker, L.: Retreat of the West Antarctic Ice Sheet from the western Amundsen Sea shelf at a pre-or early LGM stage. Quat. Sci. Rev., 91, 1-15, 2014. [gzw]

Knies, J., Vogt, C., Matthiessen, J., Nam, S. I., Ottesen, D., Rise, L., ... and Eilertsen, R. S.: Re-advance of the Fennoscandian ice sheet during Heinrich event 1. Marine Geol., 240(1-4), 1-18, 2007. [gzw]

Laberg, J. S., Eilertsen, R. S., Salomonsen, G. R., and Vorren, T. O.: Submarine push moraine formation during the early Fennoscandian Ice Sheet deglaciation. Quat. Res., 67(3), 453-462, 2007. [gzw]

145 Laberg, J. S., Eilertsen, R. S., and Vorren, T. O.: The paleo-ice stream in Vestfjorden, north Norway, over the last 35 ky: Glacial erosion and sediment yield. Geol. Soc. of Amer. Bull., 121(3-4), 434-447, 2009. [gzw]

Laberg, J. S., Kawamura, K., Amundsen, H., Baeten, N., Forwick, M., Rydningen, T. A., and Vorren, T. O.: A submarine landslide complex affecting the Jan Mayen Ridge, Norwegian-Greenland Sea: slide-scar morphology and processes of sediment evacuation. Geo-Marine Letters, 34(1), 51-58, 2014. [gzw]

150 Landvik, J. Y., Ingolfsson, O., Mienert, J., Lehman, S. J., Solheim, A., Elverhøi, A., and Ottesen, D. A. G.: Rethinking Late Weichselian ice-sheet dynamics in coastal NW Svalbard. Boreas, 34(1), 7-24, 2005. [m]

Larter, R. D. and Vanneste, L. E.: Relict subglacial deltas on the Antarctic Peninsula outer shelf. Geol., 23(1), 33-36, 1995. [gzw]

Larter, R. D., Graham, A. G., Hillenbrand, C. D., Smith, J. A., and Gales, J. A.: Late Quaternary grounded ice extent in the 155 Filchner Trough, Weddell Sea, Antarctica: new marine geophysical evidence. Quat. Sci. Rev., 53, 111-122, 2012. [gzw] Li, G., Piper, D. J., and Calvin Campbell, D.: The Quaternary Lancaster Sound trough-mouth fan, NW Baffin Bay. J. of Quat. Sci., 26(5), 511-522, 2011. [gzw]

Livingstone, S. J., Cofaigh, C. Ó., Stokes, C. R., Hillenbrand, C. D., Vieli, A., and Jamieson, S. S.: Glacial geomorphology of Marguerite Bay palaeo-ice stream, western Antarctic Peninsula. J. of Maps, 9(4), 558-572, 2013. [gzw]

Lowe, A. L. and Anderson, J. B.: Reconstruction of the West Antarctic ice sheet in Pine Island Bay during the Last Glacial Maximum and its subsequent retreat history. Quat. Sci. Rev., 21(16-17), 1879-1897, 2002. [gzw]

Lucchi, R. G., Pedrosa, M. T., Camerlenghi, A., Urgeles, R., De Mol, B., and Rebesco, M.: Recent submarine landslides on the continental slope of Storfjorden and Kveithola Trough-Mouth Fans (north west Barents Sea). In Submarine mass movements and their consequences (pp. 735-745). Springer, Dordrecht, 2012. [gzw]

Mackintosh, A., Golledge, N., Domack, E., Dunbar, R., Leventer, A., White, D., ... and Gore, D.: Retreat of the East Antarctic ice sheet during the last glacial termination. Nat. Geo., 4(3), 195, 2011. [gzw]

Mäkinen, K., Palmu, J. P., Teeriaho, J., Rönty, H., Rauhaniemi, T., and Jarva, J.: Nationally valuable moraine formations. The Finnish Environment, 14, 2007. [m]

McMullen, K., Domack, E., Leventer, A., Olson, C., Dunbar, R., and Brachfeld, S.: Glacial morphology and sediment formation in the Mertz Trough, East Antarctica. Palaeogeog., Palaeoclim., Palaeoeco., 231(1-2), 169-180, 2006. [gzw] 
Mosola, A. B. and Anderson, J. B.: Expansion and rapid retreat of the West Antarctic Ice Sheet in eastern Ross Sea: possible consequence of over-extended ice streams?. Quat. Sci. Rev., 25(17), 2177-2196, 2006. [gzw]

Noormets, R., Hogan, K., Austin, W., Chauhan, T., Roy, S., Rasmussen, T., and Dowdeswell, J.: Submarine glacial landform assemblages on the outer continental shelf north of Nordaustlandet, Svalbard. In The 6th Arctic Paleoclimate and Its

175 Extremes (APEX) Meeting. Oulu University, Oululanka Research Station, Finland (p. 70), 2012. [gzw]

O'Brien, P. E., De Santis, L., Harris, P. T., Domack, E., and Quilty, P. G.: Ice shelf grounding zone features of western Prydz Bay, Antarctica: sedimentary processes from seismic and sidescan images. Ant. Sci., 11(1), 78-91, 1999. [gzw]

Ó Cofaigh, C., Pudsey, C. J., Dowdeswell, J. A., and Morris, P.: Evolution of subglacial bedforms along a paleo-ice stream, Antarctic Peninsula continental shelf. Geophysical Research Letters, 29(8), 2002. [gzw]

180 Ó Cofaigh, C., Dowdeswell, J. A., Allen, C. S., Hiemstra, J. F., Pudsey, C. J., Evans, J., and Evans, D. J.: Flow dynamics and till genesis associated with a marine-based Antarctic palaeo-ice stream. Quat. Sci. Rev., 24(5-6), 709-740, 2005. [gzw] Ó Cofaigh, C., Larter, R. D., Dowdeswell, J. A., Hillenbrand, C. D., Pudsey, C. J., Evans, J., and Morris, P.: Flow of the West Antarctic Ice Sheet on the continental margin of the Bellingshausen Sea at the Last Glacial Maximum. JGR: Solid Earth, 110(B11), 2005. [gzw]

185 Ó Cofaigh, C., Dowdeswell, J. A., Evans, J., and Larter, R. D.: Geological constraints on Antarctic palaeo-ice-stream retreat. ESPL, 33(4), 513-525, 2008. [gzw]

Ó Cofaigh, C., Dunlop, P., and Benetti, S.: Marine geophysical evidence for Late Pleistocene ice sheet extent and recession off northwest Ireland. Quat. Sci. Rev., 44, 147-159, 2012. [m]

Ó Cofaigh, C., Benetti, S., Dunlop, P., and Monteys, X.: Arcuate moraines on the continental shelf NW of Ireland. Geol.

190 Soc., London, Memoirs, 46(1), 253-254, 2016. [m]

Ojala, A. E. K., Putkinen, N., Palmu, J. P., and Nenonen, K.: Characterization of De Geer moraines in Finland based on LiDAR DEM mapping. GFF, 137(4), 304-318, 2015. [m]

Ottesen, D., Dowdeswell, J. A., and Rise, L.: Submarine landforms and the reconstruction of fast-flowing ice streams within a large Quaternary ice sheet: the 2500-km-long Norwegian-Svalbard margin (57-80 N). Geol.Soc. of Amer. Bull., 117(7-8), 1033-1050, 2005. [m]

Ottesen, D. A. G., Dowdeswell, J. A., Landvik, J. Y., and Mienert, J.: Dynamics of the Late Weichselian ice sheet on Svalbard inferred from high-resolution sea-floor morphology. Boreas, 36(3), 286-306, 2007. [m, gzw]

Ottesen, D., Stokes, C. R., Rise, L., and Olsen, L.: Ice-sheet dynamics and ice streaming along the coastal parts of northern Norway. Quat. Sci. Rev., 27(9-10), 922-940, 2008. [gzw]

200 Ottesen, D. and Dowdeswell, J. A.: An inter-ice-stream glaciated margin: Submarine landforms and a geomorphic model based on marine-geophysical data from Svalbard. Geol. Soc. of Amer. Bull., 121(11-12), 1647-1665, 2009. [m]

Pedrosa, M. T., Camerlenghi, A., De Mol, B., Urgeles, R., Rebesco, M., and Lucchi, R. G.: Seabed morphology and shallow sedimentary structure of the Storfjorden and Kveithola trough-mouth fans (North West Barents Sea). Marine Geol., 286(1), 65-81, 2011. [gzw]

205 Rebesco, M., Liu, Y., Camerlenghi, A., Winsborrow, M., Laberg, J. S., Caburlotto, A., ... and Tomini, I. (2011). Deglaciation of the western margin of the Barents Sea Ice Sheet-A swath bathymetric and sub-bottom seismic study from the Kveithola Trough. Marine Geol., 279(1-4), 141-147. [gzw]

Rebesco, M., Domack, E., Zgur, F., Lavoie, C., Leventer, A., Brachfeld, S., ... and Smith, J.: Boundary condition of grounding lines prior to collapse, Larsen-B Ice Shelf, Antarctica. Science, 345(6202), 1354-1358, 2014. [gzw]

210 Ryan, J. C., Dowdeswell, J. A., and Hogan, K. A.: Three cross-shelf troughs on the continental shelf of SW Greenland from Olex data. Geol. Soc., London, Memoirs, 46(1), 167-168, 2016. [gzw]

Rydningen, T. A., Vorren, T. O., Laberg, J. S., and Kolstad, V.: The marine-based NW Fennoscandian ice sheet: glacial and deglacial dynamics as reconstructed from submarine landforms. Quat. Sci. Rev., 68, 126-141, 2013. [gzw] 
Shipp, S. and Anderson, J. B.: Grounding zone wedges on the Antarctic continental shelf, Ross Sea. In Glaciated Continental 215 Margins (pp. 104-105). Springer, Dordrecht, 1997. [gzw]

Shipp, S., Anderson, J., and Domack, E.: Late Pleistocene-Holocene retreat of the West Antarctic Ice-Sheet system in the Ross Sea: part 1—geophysical results. Geol. Soc. of Amer. Bull., 111(10), 1486-1516, 1999. [gzw]

Smith, J. A., Hillenbrand, C. D., Kuhn, G., Larter, R. D., Graham, A. G., Ehrmann, W., ... and Forwick, M.: Deglacial history of the West Antarctic Ice Sheet in the western Amundsen Sea embayment. Quat. Sci. Rev., 30(5), 488-505, 2011. [gzw]

Svendsen, J. I., Mangerud, J., Elverhøi, A., Solheim, A., and Schüttenhelm, R. T.: The Late Weichselian glacial maximum on western Spitsbergen inferred from offshore sediment cores. Marine Geol., 104(1-4), 1-17, 1992. [gzw]

Svendsen, J. I., Elverhøi, A., and Mangerud, J.: The retreat of the Barents Sea Ice Sheet on the western Svalbard margin. Boreas, 25(4), 244-256, 1996.

225 Todd, B. J., Valentine, P. C., Longva, O., and Shaw, J.: Glacial landforms on German Bank, Scotian Shelf: evidence for Late Wisconsinan ice-sheet dynamics and implications for the formation of De Geer moraines. Boreas, 36(2), 148-169, 2007. [m] Todd, B. J.: De Geer moraines on German Bank, southern Scotian Shelf of Atlantic Canada. Geol. Soc., London, Memoirs, 46(1), 259-260, 2016. [m]

Todd, B. J., Shaw, J., and Valentine, P. C.: Submarine glacial landforms on the Bay of Fundy-northern Gulf of Maine continental shelf. Geol. Soc., London, Memoirs, 46(1), 429-436, 2016. [m]

Vanneste, L. E. and Larter, R. D.: Deep-Tow Boomer Survey on the Antarctic Peninsula Pacific Margin: An Investigation of the Morphology and Acoustic Characteristics of the Late Quaternary Sedimentary Deposits on the Outer Continental Shelf and Upper Slope (pp. 97-121). AGU, 1995. [gzw]

Vorren, T. O. and Plassen, L. I. V.: Deglaciation and palaeoclimate of the Andfjord-Vågsfjord area, North

235 Norway. Boreas, 31(2), 97-125, 2002. [gzw]

Winsborrow, M. C., Andreassen, K., Corner, G. D., and Laberg, J. S.: Deglaciation of a marine-based ice sheet: Late Weichselian palaeo-ice dynamics and retreat in the southern Barents Sea reconstructed from onshore and offshore glacial geomorphology. Quat. Sci. Rev., 29(3-4), 424-442, 2010. [gzw]

Winsborrow, M. C., Stokes, C. R., and Andreassen, K.: Ice-stream flow switching during deglaciation of the southwestern 240 Barents Sea. Geol. Soc. of Amer. Bull., 124(3-4), 275-290, 2012. [gzw]

Zilliacus, H.: Genesis of De Geer moraines in Finland. Sedimentary Geol., 62(2-4), 309-317, 1989. [m] 